\title{
Development and Validation of a Highly Sensitive Radioimmunoassay for Chinook Salmon (Oncorhynchus tshawytscha) Growth Hormone
}

\author{
P. Y. Le Bail, ${ }^{1}$ J. P. Sumpter, ${ }^{*}$ J. F. Carragher, ${ }^{*}$ B. Mourot, P. D. Niu, and \\ C. WEIL
}

Laboratoire de Physiologie des Poissons, INRA, Campus de Beaulieu. 35042 Rennes Cédex, France; and * Department of Biology and Biochemistry, Brunel University, Uxbridge.

Middlesex UB8 $3 P H$. United Kingdom

Accepted August 2, 1990

\begin{abstract}
This study describes the development of a highly specific and very sensitive radioimmunoassay for salmonid growth hormone. Antiserum raised against chinook (Oncorhynchus tshawytscha) GH2, which did not recognize ${ }^{125}$ I-sPRL and ${ }^{125}$ I-sGTH (at 1:1000 initial dilution), was able to inhibit growth when injected into rainbow trout (Oncorhynchus mykiss). ${ }^{125} \mathrm{I}-\mathrm{sGH} 2$, used as tracer, was not recognized by anti-sGTH or by anti-sPRL. Mammalian GH and ACTH and salmonid GTH, TSH, and PRL did not cross-react in the sGH assay. The inhibition curves for pituitary extracts and plasma from salmonids were parallel to the salmon GH standard, whereas those from carp, tilapia, and catfish showed no significant cross reactivity. The RIA ED90 and ED50 values were 0.2 and $1.5 \mathrm{ng} / \mathrm{ml}$, respectively. Using this RIA for measuring GH release by cultured pituitary cell we observed a strong inhibiting effect of SRIF $\left(10^{-6} M\right)$ and a stimulatory effect of hGRF $\left(10^{-6} M\right)$. This RIA allowed us also to detect daily fluctuations in the plasma GH concentration in cannulated rainbow trout. 1991 Academic Press. Inc
\end{abstract}

In teleosts, growth hormone (GH) exhibits a pleiotropic action. It acts on growth (see Donaldson et al., 1979), sea water adaptability (Komourdjian et al., 1976; Clarke et al., 1977; Miwa and Inui, 1985; Bolton et al., 1987a; Björnsson et al., 1987; Boeuf et al., 1990), the corticotrope axis (Young, 1988), and probably on reproduction (Le Bail, 1988; Stacey et al., 1984; Singh et al., 1988). However, investigations on its control of secretion and its mode of action are only just starting, mainly because specific immunoassays have only recently been developed.

Heterologous radioimmunoassays (RIA) were first used to estimate plasma $\mathrm{GH}$ levels of teleosts (McKeown and Van Overbeeke, 1972; Peter et al., 1976) without

\footnotetext{
${ }^{1}$ To whom reprint requests should be addressed.
}

complete validation (see Nicoll, 1975). It is now apparent that fish serum proteins can interfere with mammalian $\mathrm{GH}$ tracer (Niu et al., 1991) and thus produce an artefactual displacement. Recently, specific and sensitive GH RIAs were developed and used for measurement of serum and pituitary $\mathrm{GH}$ levels in carp (Cook et al., 1983) and eel (Kishida and Hirano, 1988). Two RIAs have also been developed for salmonid $\mathrm{GH}$ (Bolton et al., 1986; Wagner and McKeown, 1986). Their sensitivities (ED50 around $20 \mathrm{ng} / \mathrm{ml}$ ) are equivalent to those of the carp GH RIA (Cook et al., 1983), whereas the eel GH RIA (Kishida and Hirano, 1988) is considerably more sensitive. These salmonid RIAs have been used to obtain new data about serum GH levels during salmon smoltification (Sweeting $e t$ al., 1985; Bolton et al., 1986; Prunet et al., 
1989; Young et al., 1989), stunting (Bolton et al., 1987b, Björnsson et al., 1988), and sustained exercise (Barrett and McKeown, 1988). Monoclonal antibodies have also been used to develop an enzyme immunoassay for salmon GH (Furuya et al., 1987) but its sensitivity is extremely low (ED50 $=1000 \mathrm{ng} / \mathrm{ml}$ ) and hence it cannot be used to measure circulating $\mathrm{GH}$ levels.

In salmonids, two forms of $\mathrm{GH}$ are present which are probably the products of two separate genes (Sekine et al., 1989). These have been called sGH1 and sGH2, based on the order they elute from chromatographic columns during purification. Using the chinook salmon GH purified in our laboratory (Le Bail et al., 1989), we report in the present paper a radioimmunoassay considerably more sensitive than those previously described. The development of this RIA has allowed us to acquire new data concerning the variation of serum $\mathrm{GH}$ concentrations in salmonid species (Pickering et al., 1991; Sumpter et al., 1991a,b).

\section{MATERIALS AND METHODS}

Characterisation of antiserum. The anti-chinook salmon GH (anti-sGH2), obtained from a rabbit (coded $7302 \mathrm{~F}$ ), was generated against $\mathrm{sGH} 2$ as described earlier (Le Bail et al., 1989). In vivo characterisation of this antibody was done in $0+$ rainbow trout (Oncorhynchus mykiss) maintained at $12^{\circ}$ under a simulated natural photoperiod at Rennes. Three groups of 10 fish, distinguished by different Alcian blue spots, were maintained in the same tank ( 300 liters) and were fed ad libitum with commercial pellets (Aqualim) for the duration of the experiment (11 weeks). During the first 6 weeks the fish were injected two times per week with $0.9 \% \mathrm{NaCl}$ normal rabbit serum or anti-chinook salmon GH ( $20 \mu \mathrm{l}$ or $40 \mu \mathrm{l})$. The fish were starved for two days before weighing.

Iodination of $s G H$. Purified chinook salmon $\mathrm{GH} 2$ (Le Bail et al., 1989) was iodinated according to the chloramine-T method (Greenwood et al., 1963) modified by Martal (1972). Five micrograms of $\mathrm{sGH} 2$ was dissolved in $5 \mu \mathrm{l}$ phosphate buffer $(300 \mathrm{mM}$, pH 7.5) and $500 \mu \mathrm{Ci} \mathrm{Na}{ }^{125} \mathrm{I}$ in $5 \mu \mathrm{I} \mathrm{NaOH}$ (IMS-30, Amersham) and $5 \mu \mathrm{l}$ chloramine-T $(80 \mu \mathrm{g} / \mathrm{ml}$ phosphate buffer) were then added. The reaction at $20^{\circ}$ was stopped after $90 \mathrm{sec}$ by the addition of $5 \mu \mathrm{l}$ of sodium metabisulfite
( $80 \mu \mathrm{g} / \mathrm{ml}$ phosphate buffer). Free iodine was separated from the labelled hormone by gel filtration on Sephadex G-25 (PD10 column, Pharmacia) using 50 $\mathrm{m} M$ Tris-HCl, $1 \%$ BSA, $0.5 \% \mathrm{NaN}_{3}$ (pH 7.5) buffer. Specific activity was estimated (about $80 \mu \mathrm{Ci} / \mu \mathrm{g}$ ) from the rate of iodine incorporation into $\mathrm{GH}$. Labelled hormone was stored either at $4^{\circ}$ or in $50 \%$ glycerol at $-20^{\circ}$.

Radioimmunoassay procedure. The RIA was performed using a double-antibody method under nonequilibrium conditions. Assay buffer was $50 \mathrm{~m} M$ TrisIICl (pII 7.8), 1\% BSA, 0.5\% $\mathrm{NaN}_{3}, 0.1 \%$ Triton X100. Standard, plasma, and pituitary extracts were diluted in this buffer and assayed in duplicate in $100-\mu \mathrm{l}$ volumes. $100 \mu \mathrm{l}$ of anti-s $\mathrm{GH}_{2}$ (diluted to $1: 30,000$ in buffer containing $0.25 \%$ normal rabbit serum) was added. After $24 \mathrm{hr}$ at $20^{\circ}, 100 \mu \mathrm{l}$ of iodinated $\mathrm{sGH}$ ( 8000 to $10,000 \mathrm{cpm}$ ) was added and the incubation was continued for a further $24 \mathrm{hr}$. The method used for separation of antibody bound from free labelled $\mathrm{GH}$ depended on the nature of the unknown sample. For plasma samples, $100 \mu l$ of 1:5 sheep anti-rabbit $\gamma$-globulin in distilled water was added. For pituitary extracts or culture medium, $200 \mu \mathrm{l}$ of 1:20 sheep antirabbit $\gamma$-globulin in $7.5 \%$ polyethylene glycol (PEG) was added. We used PEG precipitation for pituitary extracts and culture medium because this method of precipitation produces a larger, firmer pellet. Ilowever, when used with plasma amples, PEG precipitation produces a higher nonspecific binding than second-antibody precipitation and, further, the nonspecific binding is variable, depending on the nis of the plasma (this is a consequence of the protein and lipid levels in plasma varying appreciably, especially during sexual maturation in females). After $24 \mathrm{hr}$, each tube received $3 \mathrm{ml}$ of $10 \mathrm{mM}$ Tris- $\mathrm{HCl}$ buffer $(\mathrm{pH} \mathrm{7.8)}$ and was centrifuged $(4,000 \mathrm{~g})$ for $1 \mathrm{hr}$ at $4^{\circ}$. The supernatant was decanted and the bound fraction was counted in an automatic gamma counter (Packard Multi-Prias 2). Nonspecific binding, obtained by substituting buffer containing normal rabbit serum for the anti-sGH2, was approximately $2 \%$ of the total radioactivity added. Radioactivity bound by the antibody in the absence of unlabelled hormone $\left(B_{0} / T\right)$ was between 25 and $30 \%$ of the total ${ }^{125} \mathrm{I}-\mathrm{sGH}$ added. Sample values were calculated using log-logit transformation.

Sources of hormones, serum, and pituitaries. Human adrenocorticotropin hormone (ACTH) and human (hGH) and bovine (bGH) growth hormone were supplied by the National Institute of Arthritis and Metabolic Diseases, NIH (Bethesda, Md). Chinook salmon prolactin (sPRL), thyrotropin (sTSH), and gonadotropin (sGTH), and sea bream growth hormone (dGH) were purified according to Prunet and Houdebine (1984), Chen, Le Bail. McKenzie and Breton, (unpublished data), Breton et al. (1978), and Pagelson, Zohar, and Le Bail (unpublished data), respectively. 
sGTH and SPRL used for cross-reactivity studies with anti-sGH2 were labelled according to the protocols described by Breton et al. (1978) and Hirano et al. (1985), respectively.

Samples from sexually mature chinook, chum $(O$. keta), and coho (O. kisutch) salmon were obtained from hatcheries in British Columbia, Canada. Mature Atlantic salmon (Salmon salar) were generously provided by Dr. G. Boeuf (IFREMER). Mature rainbow (O. mykiss), brown (S. trutta), and brook (Salvelinus fontinalis) trout, tilapia (Oreochromis niloticus), carp (Cyprinus carpio), and catfish (Chrysichthys nigrodigitatus) came from our hatchery in Rennes. Mature rainbow trout were hypophysectomized by a transorbital surgical technique (Nishioka et al., 1987). After anaesthesia (1:3000 phenoxyethanol), blood samples were taken from the caudal vessel of each fish with a heparinized hypodermic syringe. Plasma was immediately separated by centrifugation at $2000 \mathrm{~g}$ for $30 \mathrm{~min}$ at $4^{\circ}$ and frozen at $-20^{\circ}$ until assay. Pituitaries were removed from freshly killed fish and were quickly homogenized with $1 \mathrm{ml}$ of RIA buffer in a glass homogenizer. The homogenates were centrifuged at $2000 \mathrm{~g}$ for $15 \mathrm{~min}$ at $4^{\circ}$ and the supernatants frozen at $-20^{\circ}$ until assay.

Cell culture. Primary cultures of pituitary cells were used to study the regulation of GH secretion. Pituitary glands were removed from ten 3-year-old spermiating rainbow trout. Cell preparation was done according to the technique described by Weil et al. (1986). Cells were cultured for 3 days before treatment with peptide, and then for $24 \mathrm{hr}$ in the presence of the peptide. Culture medium $(250 \mu \mathrm{l})$ containing $6.25 \times 10^{4}$ cells was plated in each well of 96-well plates (NUNC). Human growth hormone-releasing factor $\left(\mathrm{hGRF}_{1-44}\right)$ and somatostatin $\left(\mathrm{SRIF}_{14}\right)$, generously supplied by Sanofi, were used at a concentration of $1 \times 10^{-6} \mathrm{M}$.

Cannulation. Individual daily profiles of serum growth hormone levels were studied in 2-year-old mature rainbow trout. Animals were cannulated according to the technique of Zohar (1980) and Bry and Zohar (1980). Five days after surgery, the fish were starved for 1 day and then sampled. Blood $(200 \mu \mathrm{l})$ was removed each hour and the total volume of blood removed over $24 \mathrm{hr}$ was around $10 \%$ of the blood volume of the fish. The fish were maintained in individual tanks under a $12.5 \mathrm{~L}-11.5 \mathrm{D}$ photoperiod at $13^{\circ}$. Changes in photophase were preceded by a $30 \mathrm{~min}$ slow decrease or increase of light.

\section{RESULTS}

\section{Characterisation of Antiserum}

After 4 weeks of injection with $20 \mu$ of anti-sGH antiserum, no significant difference in body weight was observed between

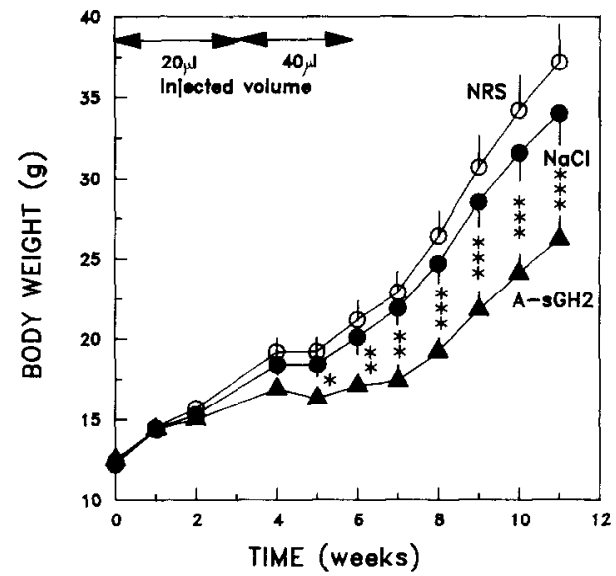

FIG. 1. Effect of anti chinook salmon GH antibody on growth of $0+$ rainbow trout. Fish received twice weekly intraperitoneal injections $(20$ or $40 \mu l)$ of $\mathrm{NaCl}$ $(0.9 \%)$, normal rabbit serum (NRS), or anti chinook salmon $\mathrm{GH}$ (A-sGH2). Vertical lines represent standard deviations and each point is the mean of $10 \mathrm{val}$ ues. Significant differences from controls (Student's $t$ test) are as follows: ${ }^{*}(0.05),{ }^{* *}(0.01),{ }^{* * *}(0.001)$.

control and treated animals (Fig. 1). Forty microliters was injected during the last 3 weeks, at the end of which the body weight was significantly lower in treated fish.

In excess concentration, anti-sGH bound about $90 \%$ of the labelled sGH (Fig. 2) and $30 \%$ binding $\left(B_{0} / T\right)$ was obtained with an initial dilution of 1:30,000 (final dilution $1: 90,000$ ); this dilution was used subse-

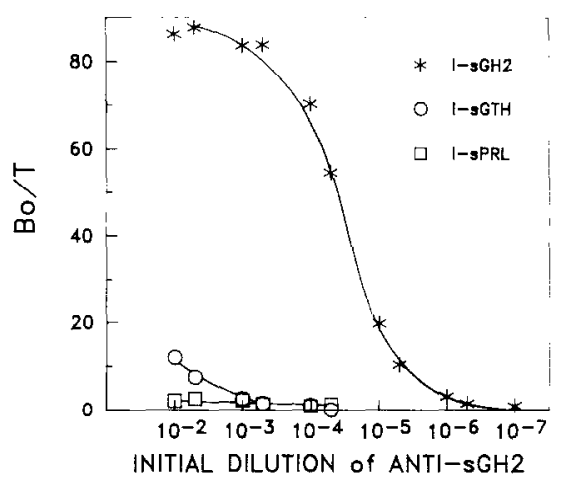

FIG. 2. The cross-reactivity of anti chinook salmon GH antibody (anti-sGH2) with ${ }^{123} \mathrm{I}-\mathrm{sPRL},{ }^{12} \mathrm{I}$-sGTH, and ${ }^{125} \mathrm{I}-\mathrm{sGH} 2$. Each point is the mean of duplicate determinations. Specific binding $\left(B_{0}\right)$ was expressed as percentage of total ${ }^{125}$ I-hormone added (T). 
quently in the assay. No significant crossreactivity was observed with labelled sPRL, but $10 \%$ of labelled sGTH was bound at the 1:100 dilution of anti-sGH. This dilution is 1000 -fold more concentrated than the dilution necessary to bind the same percentage of $\mathrm{sGH}$ (Fig. 2).

\section{Characterization of the ${ }^{125} \mathrm{I}-\mathrm{sGH}$}

Chromatography of the freshly labelled hormone on PD10 columns resulted in a single protein peak from which each fraction bound with the same affinity to antibody in excess (data not shown). The binding of iodinated $\mathrm{sGH}$ stored in various ways is shown in Fig. 3. When the iodinated hormone was kept at $4^{\circ}$ binding activity decreased fairly rapidly, whereas when maintained at $-20^{\circ}$ in the presence of glycerol, the iodinated hormone deteriorated much more slowly. After 40 days, rechromatography (on $\mathrm{PD} 10$ ) of the iodinated hormone restored most of the initial binding (data not shown). Anti-sGTH and anti-sPRL did not display any significant specific binding to ${ }^{125}$ I-sGH2 (data not shown), demonstrating that these antisera are also specific.

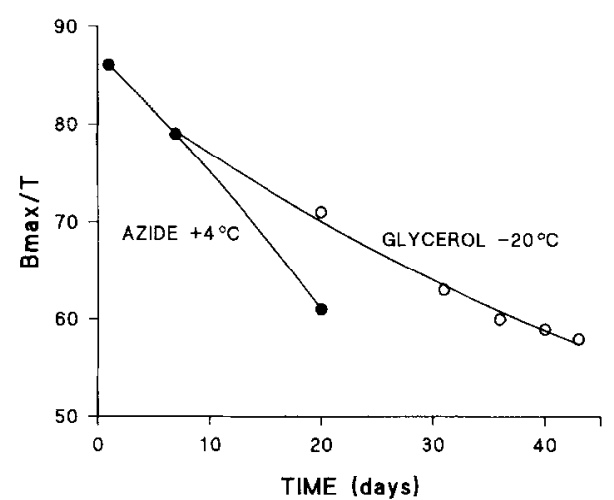

FIG. 3. Evolution of the maximum specific binding $\left(B_{\max }\right)$ of ${ }^{125} \mathrm{I}-\mathrm{sGH} 2 \mathrm{kept}$ at $4^{\circ}$ in the presence of azide $(0.05 \%)$ or at $-20^{\circ}$ in the presence of $2 \mathrm{vol}$ of glycerol. The labelled sGH2 $(10,000 \mathrm{cpm})$ was incubated with an excess of anti-sGH2 (1:100 initial dilution). Each point is the mean of quadruplicate determinations. Maximum specific binding was expressed as percent of added radioactivity $\left(B_{\max } / \mathrm{T}\right)$.
Specificity of the Assay

Figure 4 presents the specificity of the chinook salmon GH RIA with other pituitary hormones. sGH1 appeared a little more potent than sGH2: for the subsequent work, a mixture of these two forms (around $50 \%$ of each) was used as the standard. With this mixture, $10 \%$ inhibition of maximum binding was obtaincd with $0.2 \mathrm{ng} / \mathrm{ml}$, and the ED50 of the RIA varied from 1.5 to $2 \mathrm{ng} / \mathrm{ml}$. dGH also inhibited the binding of ${ }^{125} \mathrm{I}-\mathrm{sGH}$, but only at concentrations more than 1000-fold higher than when using sGH. One microgram per milliliter of chinook salmon PRL and GTH, human ACTH and $\mathrm{GH}$, and bovine $\mathrm{GH}$ did not produce any displacement of the iodinated sGH.

Serial dilutions of pituitary extracts from the different salmonid species tested all gave displacement curves whose slopes were not significantly different from that of the sGH standard curve (Fig. 5). Carp, catfish, and tilapia pituitary extracts did not cross-react in the RIA at dilutions below 1:400. Figure 6 shows that no significant cross-reaction occurred with $100 \mu$ l of hypophysectomized trout plasma, or with

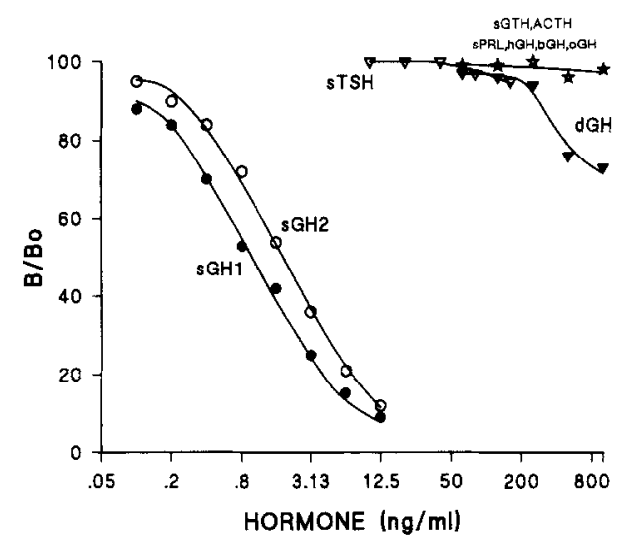

FIG. 4. Dose-response inhibition curves for chinook salmon growth hormones $\left(\mathrm{sGH}_{1}, \mathrm{sGH}_{2}\right)$, prolactin (sPRL), gonadotropin ( $\mathrm{sGTH}$ ), and thyrotropin (sTSH); for sea beam (dGH), human (hGH), and bovine (bGH) growth hormones; and for human corticotropin hormone (ACTH). Each point is the mean of duplicate determinations. 


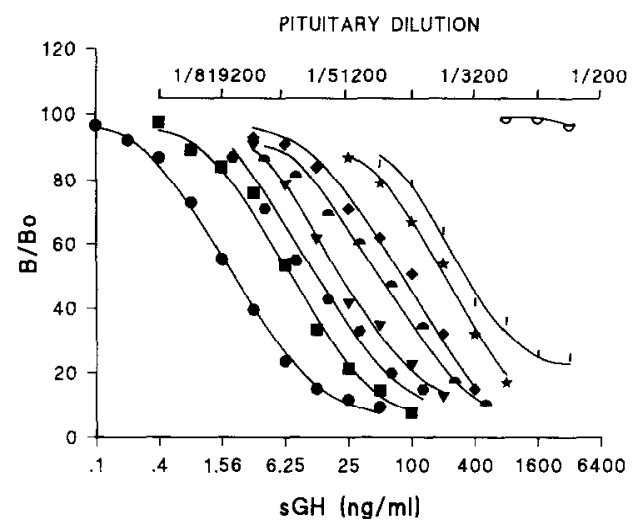

FIG. 5. Dose-response inhibition curves for chinook salmon GH1 +2 standard $(O)$ and serial dilutions of crude pituitary extracts from different fish species: rainbow $(\boldsymbol{\nabla})$, brown $(\boldsymbol{\Theta})$, and brook ( 1 ) trout; chinook ( $\mathbf{0})$, coho $(\bullet)$, chum $(\star)$, and Atlantic salmon (C); carp, tilapia, and catfish $(\checkmark)$. Each point is the mean of duplicate determinations.

plasma from intact catfish, tilapia, carp, and sheep. The displacement curves for plasma from chinook, coho, chum, and Atlantic salmon, and rainbow and brown trout were all parallel to the chinook GH standard curve. Repeated determinations of the $\mathrm{GH}$ concentration of a single rainbow trout serum sample (mean of many estimates: $1.01 \mathrm{ng} / \mathrm{ml}$ ) gave intraassay and interassay

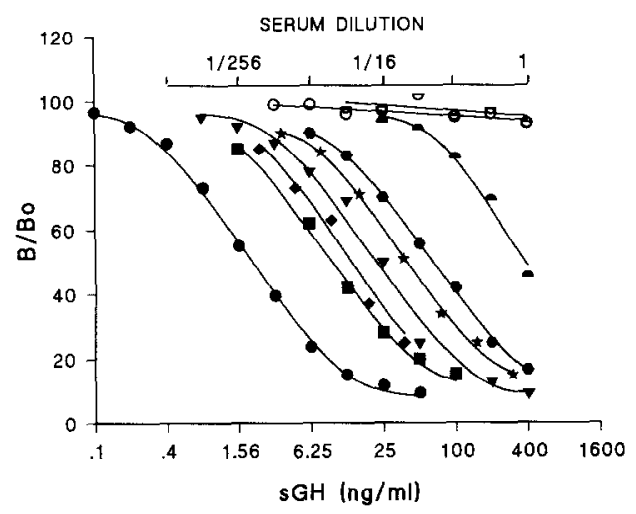

FIG. 6. Dose-response inhibition curves for chinook salmon GH1 + 2 standard (O) and serial dilution of plasma from different species: normal $(\boldsymbol{\nabla})$ and hypex $(\bigcirc)$ rainbow trout; brown trout $(\boldsymbol{\oplus})$; chinook $(\boldsymbol{\square})$, coho $(\star)$, chum $(\star)$, and Atlantic (C) salmon; carp, tilapia, catfish, and sheep $(\square)$. Each point is the mean of duplicate determinations. coefficients of variation of $4 \%(n=8)$ and $8.3 \%(n=10)$, respectively.

Recovery experiments were conducted by measuring chinook salmon $\mathrm{sGH}$ when added in increasing concentration to $50 \mu \mathrm{l}$ of plasma from hypophysectomized trout (Fig. 7). The slope of the regression line, calculated using $\mathrm{GH}$ values up to $4.5 \mathrm{ng} / \mathrm{ml}$, was equivalent to 1 . For the values higher than $4.5 \mathrm{ng} / \mathrm{ml}$, a slight overestimatc of the true $\mathrm{GH}$ concentration was observed.

Different anticoagulent or serum protective factors such as heparin $(100 \mathrm{U} / \mathrm{ml})$, aprotinin (5 TIU/ml), EDTA $(50 \mathrm{~m} M)$, and trypsin inhibitor $(100 \mu \mathrm{g} / \mathrm{ml})$, when added to the assay buffer, had no effect on the $B_{0}$ value (data not shown), nor did they alter the GH estimate when they were added to fresh serum.

\section{In Vitro and In Vivo Experiments}

Pituitary somatotroph cells in the control cultures released very high amounts of $\mathrm{GH}$ $(628 \mathrm{ng} / \mathrm{ml})$ during a $24-\mathrm{hr}$ incubation period (Fig. 8). Addition of human GRF $\left(1 \times 10^{-6}\right.$ $M)$ or SRIF $\left(1 \times 10^{-6} M\right)$ increased 3-fold, or decreased 50 -fold, respectively, the GH concentration in the culture medium (Fig. 8).

We studied the individual daily plasma

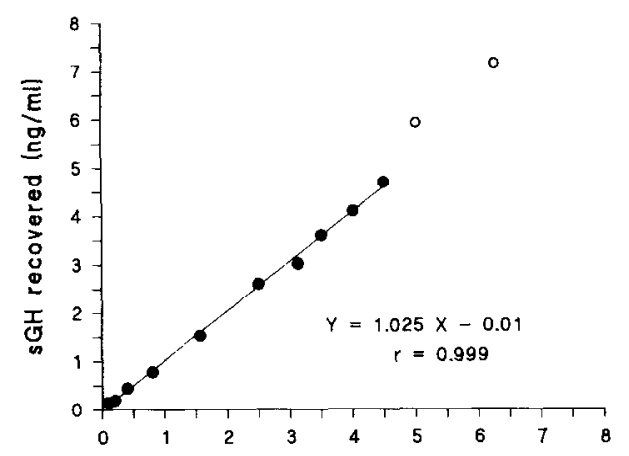

sGH added to $50 \mu$ of hypex trout plasma (ng/ml)

FIG. 7. Recovery of chinook salmon GH added to $50 \mu l$ of hypophysectomized rainbow trout plasma in comparison with the theoretical amount expected. Each point is the mean of duplicate determinations. Values used $(O)$ or not used $(O)$ for the line of best fit. 


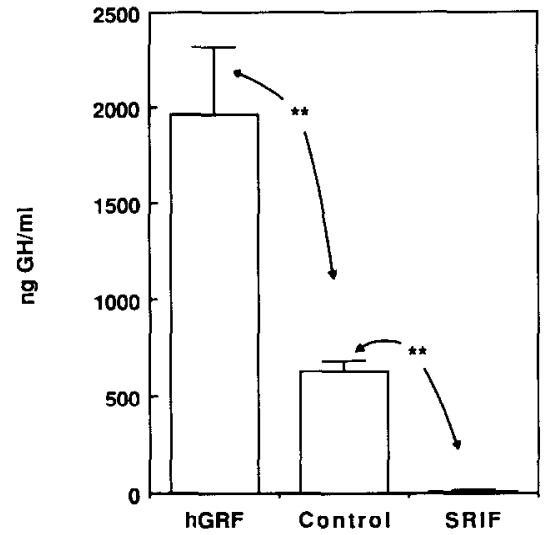

FIG. 8. Effect of human growth hormone releasing factor (hGRF, $10^{-6} M$ ) and somatostatin (SRIF ${ }_{14}$, $10^{6} M$ ) on GH secretion by rainbow trout pituitary cell cultures. Mean and standard deviation were calculated from four wells. Comparisons between groups were made using the Wilcoxon-Mann-Whitney test. ${ }^{* *} P<0.01$.

GH profiles of nine mature rainbow trout (five spermiating males and four postovulatory females). Fluctuations in GH levels were observed in all fish studied (Fig. 9). The GH profiles from three animals which refused food before the sampling period (fish 1, 2, and 4) were not obviously different from those of the other fish. Basal GH levels (the levels between peaks) were 1 $\mathrm{ng} / \mathrm{ml}$ or less. The frequency and timing of the GH peaks did not appear to be highly synchronized with the photoperiod, but no analysis was done to confirm or refute this. Absolute values of the amplitudes of the $\mathrm{GH}$ peaks varied between fish.

\section{DISCUSSION}

Before developing the RIA, the quality of the anti-sGH2 was assessed in various ways. Anti-sGH2 (7302F) appeared very specific to $\mathrm{sGH}$ : it did not recognize ${ }^{125} \mathrm{I}$ sPRL and the very low cross reactivity observed with ${ }^{125}$ I-sGTH occurred only with very high concentrations of antibody. These data confirm the high specificity of the antibody for sGH, as previously observed by immunocytochemistry (Le Bail et al., 1989). Fish injected with anti-sGH2 displayed a slower rate of growth than control fish. This antibody, generated from a biologically active hormone (Le Bail et al., 1989), bound around $90 \%$ of ${ }^{125} \mathrm{I}-\mathrm{sGH} 2$. These results indicate that anti-sGH2 can recognize biologically active salmon growth hormone.

The suitability of the ${ }^{125} \mathrm{I}$-sGH for use in the RIA was also confirmed in several ways. All fractions of sGH obtained by gelfiltration showed a similar capacity to bind anti-sGH2, as well as bind to the liver GH receptor (Yao et al., 1991). The specific activity of the ${ }^{125} \mathrm{I}$-sGH was 20 -fold higher than previously reported for chum GH (Bolton et al., 1986), which was one factor responsible for the greater sensitivity of our GH RIA. The absence of cross-reactivity with anti-sPRL and anti-sGTH confirms the high purity of the sGH2 previously reported (Le Bail et al., 1989) and also the specificity of these two antibodies, which have been used to develop sGTH (Breton et al., 1978) and sPRL (Hirano et al., 1985) RIAs. The stability of ${ }^{125} \mathrm{I}$-sGH when maintained at $-20^{\circ}$ in the presence of glycerol permitted its use for 3 months.

Using anti-sGH2 at 1:90,000 final dilution, the assay showed a very high degree of specificity for sGH. No cross-reaction was observed with salmonid PRL, GTH, TSH, and mammalian ACTH. Mammalian GH did not crossreact, but sea bream GH, at very high concentrations, showed some cross-reactivity. This last result contrasts with the high degree of cross-reactivity of sea bream GH observed in a salmonid GH radioreceptor assay (Yao et al., 1991). The absence of cross-reactivity by carp, tilapia, and catfish crude pituitary extracts confirms the high specificity of the assay for salmonid GH. Furthermore, pituitary extracts from all salmonid species produced displacement curves parallel to that of the sGH standard. Pituitary extract from brook trout was the least potent of those tested, and also showed an incomplete inhibition 

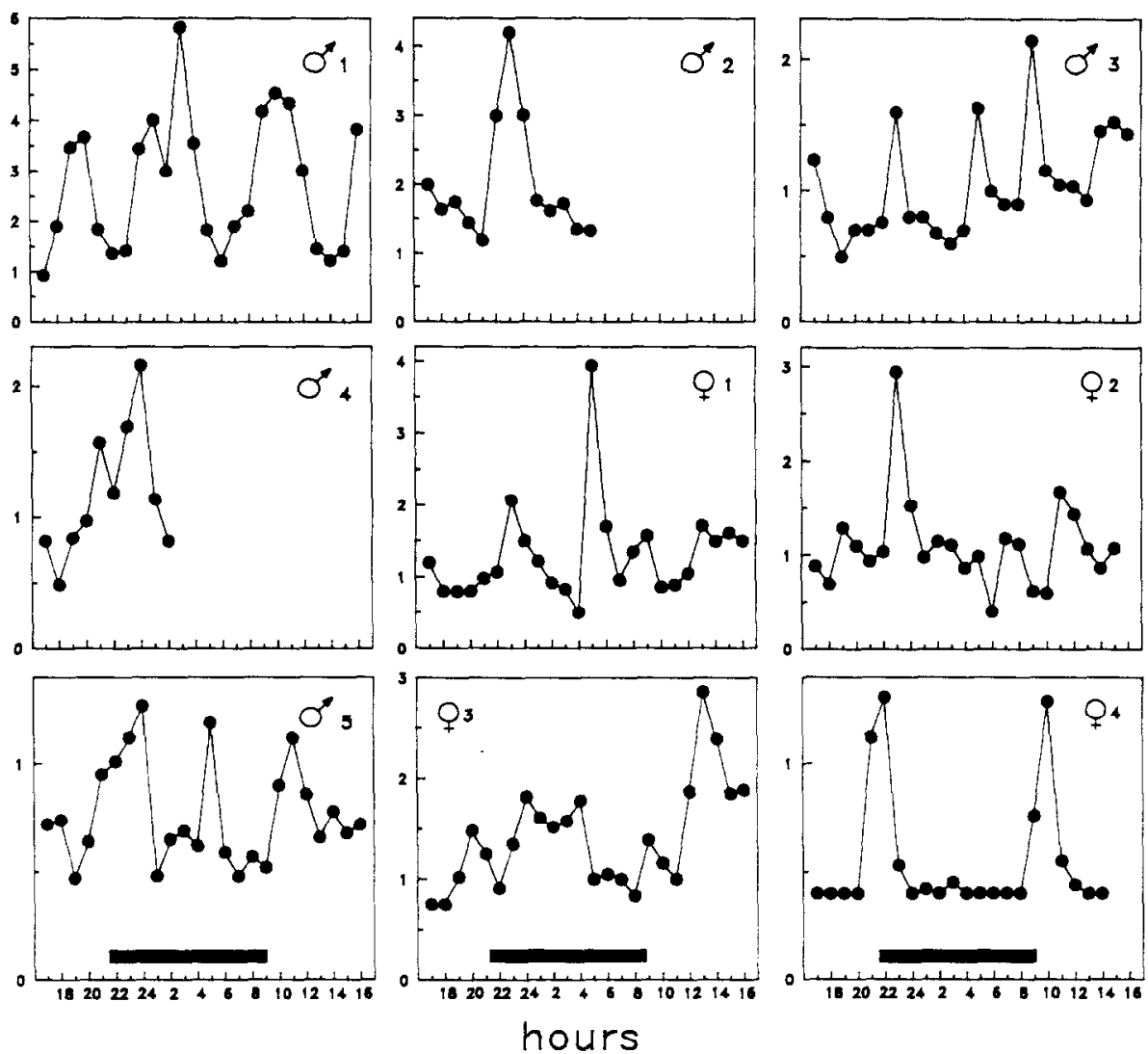

FIG. 9. Individual daily profiles of serum growth hormone levels from nine catheterized rainbow trout. $200 \mu \mathrm{l}$ of blood were sampled each hour for $\mathrm{GH}$ determination. The dark horizontal bars correspond to the dark photophase, which werc preceded and followed by a 30-min slow decrease or increase of light, respectively.

curve. This may mean that significant structural differences exist between GH from Salvelinus and Oncorhynchus genus; however, other interpretations are possible, such as a low GH content in the Salvelinus pituitary gland we used.

The antiserum did not distinguish between $\mathrm{sGH} 1$ and $\mathrm{sGH} 2$, which gave parallel displacement curves, although sGH1 appeared two times more potent than $\mathrm{sGH} 2$. Using a mixed preparation of the two hormones as standard, the ED50 varied from 1.5 to $2 \mathrm{ng} / \mathrm{ml}$, which is 10 -fold lower than the equivalent values reported by Bolton $e t$ al. (1986) and Wagner and McKeown (1986) in their chum GH RIAs. Such variation between assays can be produced by a number of factors, such as the specific activity of the labelled hormone, the affinity constant of the antibody, assay procedure, or the quality of the cold standard (Reiter et al., 1988). For the latter case this may be caused by partial solubilization of the $\mathrm{GH}$ standard, leading to a higher apparent ED50, as well as a higher estimated GH concentration in samples without any real change in sensitivity. It is equally possible that the various standards employed in the different sGH RIAs reported are of different purity, or dissimilar immunological potency. The same reference sample should be tested in the different salmonid GH assays to examine these hypotheses. It should be emphasized that our results, re- 
ported in this and the accompanying papers (Pickering et al., 1991; Sumpter et al., 1991a,b), demonstrate that because plasma GH levels in healthy, rapidly growing trout are low, a very sensitive RIA is required if normal plasma $\mathrm{GH}$ levels are to be quantified with any acceptable degree of accuracy.

The assay we have developed can be used to estimate plasma GH levels, since salmonid serum produced parallel displacement curves to the sGH standard, whereas serum from nonsalmonid species or hypophysectomized rainbow trout did not cause significant displacement of the label. Furthermore, complete recovery and small intra- and interassay variations permit the estimation of sample GH values with a high degree of confidence. It should be mentioned that the plasmas used for the parallelism studies (see Fig. 6) were chosen because they had high GH levels, allowing a full inhibition curve to be obtained (the average $\mathrm{GH}$ value was around $10 \mathrm{ng} / \mathrm{ml}$ ). These plasma samples were obtained from sexually mature fish which had probably not eaten for a considerable time. It is likely that these circumstances contributed significantly to their high GH levels (see Sumpter et al., 1991a,b, for a full discussion on the effects of sexual maturation and starvation on plasma GH levels in salmonids). We have found that plasma samples from sexually immature, juvenile chum salmon contain low GH levels (our unpublished results).

Among hypothalamic hypophysiotropic factors implicated in the control of secretion of pituitary hormones in mammals, SRIF and GRF are considered to be the most specific for GH (review of Kordon, 1985; Muller, 1987). Our in vitro results, which show a stimulation (300\%) by GRF and a very strong inhibition ( $98 \%$ ) by SRIF of GH release by pituitary cells, are in accordance with the mammalian data. The responsiveness of the pituitary cells in primary culture to these neurohormones indi- cates that this technique, previously established for studying GtH secretion (Weil et al., 1986), can also be used for studies on GH secretion. In teleosts, where the inhibitory effect of SRIF has been clearly demonstrated (Nishioka et al., 1988), results obtained with GRF are inconclusive. In goldfish (Carassius auratus), GRF had either little (Peter et al., 1984) or no effect (Marchant and Peter, 1989), whereas a stimulatory effect was found in salmonids (Luo and McKeown, 1989). Technical problems or species differences may explain these inconclusive results. Prcvious variable findings might also be explained by the different nature of the GRF peptides tested.

In mammals, pulsatile GH secretion is well established and characterized (review of Daughaday, 1980; Muller, 1987). The daily plasma $\mathrm{GH}$ profiles obtained from individual cannulated rainbow trout indicate that pulsatile secretion exists also in trout, at least under the conditions of the present study. Basal levels were fairly consistent, and varied between 0.5 and $1 \mathrm{ng} / \mathrm{ml}$, whereas peak values were different between fish and were not apparently linked to specific physiological events (stress, sex, feeding, etc.). The peaks are very unlikely to be attributable to assay artefacts because many of them are comprised of a number of points (see especially male 1 and female 4 of Figure 9). Computer analysis is required to more clearly define the pulsatile characteristics of our results. However, our results can be considered only preliminary since numerous parameters were not taken into account. Indeed, the plasma GH level can be modified by stress (Pickering et al., 1991), starvation (Barrett and McKeown. 1988; Sumpter et al., 1991a), sexual maturation (Marchant and Peter, 1986; Stacey et al., 1984; Sumpter et al., 1991b), and season (Marchant and Peter, 1986). The results from these studies suggest that even if the plasma GH level fluctuates episodically in free-swimming fish (it should be empha- 
sized that our results were obtained from cannulated fish), the amplitude of the episodes is not high enough to mask an overall effect of other parameters. However, considerably more work is required to assess the degree of importance of the many parameters already known to effect plasma $\mathrm{GH}$ levels.

\section{ACKNOWLEDGMENTS}

We are indebted to the National Institute or Arthritis, Diabetes, Digestive and Kidney diseases and to Sanofi for the purified, synthetic, or recombinant hormones. We are especially grateful to Dr. Breton and Dr. Prunet for their gifts of chinook salmon GTH and PRL. We thank J. C. Poirier and G. Boeuf who provided us with sheep and salmon serum. This work is the result of investigations supported by a grant from GCS "Bases Biologiques de l'Aquaculture," and from the "Etablissement Public Regional de Bretagne."

\section{REFERENCES}

Barrett, B. A., and McKeown, B. A. (1988). Sustained exercise augments long-term starvation increases in plasma growth hormone in the steelhead trout, Salmo gairdneri. Can. J. Zool. 66, 853-855.

Björnsson, B. T., Yamauchi, K., Nishioka, R. S., Deftos, L. J., and Bern. H. A. (1987). Effects of hypophysectomy and subsequent hormonal replacement therapy on hormonal and osmoregulatory status of coho salmon, Oncorhynchus kisutch. Gen. Comp. Endocrinol. 68, 421-430.

Björnsson, B. T., Ogasawara, T., Hirano, T., Bolton, J. P., and Bern, H. A. (1988). Elevated growth hormone levels in stunted atlantic salmon, Salmo salar. Aquaculture 73, 275-281.

Boeuf, G., Prunet, P., Le Bail, P.-Y. (1990). Un traitement l'hormone de croissance peut-il stimuler la smoltification du saumon Atlantique? C.R. Acad. Sci. 310 (III), 75-80.

Bolton, J. P., Takahashi, A., Kawauchi, H., Kubota, J., and Hirano, T. (1986). Development and validation of a salmon growth hormone radioimmunoassay. Gen. Comp. Endocrinol. 62, 230-238.

Bolton, J. P.. Collie, N. L., Kawauchi, H., and Hirano, T. (1987a). Osmoregulatory actions of growth hormone in rainbow trout (Salmo gairdneri). J. Endocrinol. 112, 63-68.

Bolton, J. P., Young, G., Nishioka, R. S., Hirano, T., and Bern, H. A. (1987b). Plasma growth hormone levels in normal and stunted yearling coho salmon, Oncorhynchus kisutch. J. Exp. Zool. 242, 376-382.
Breton, B., Prunet, P., and Reinaud, P. (1978). Sexual differences in salmon gonadotropin. Ann. Biol. Anim. Biochim. Biophys. 18, 759-765.

Bry, C., and Zohar, Y. (1980). Dorsal aorta catheterization in rainbow trout (Salmo gairdneri). II. Glucocorticoid levels, hematological data and resumption of feeding for five days after surgery. Reprod. Nutr. Dev. 20, 1825-1834.

Clarke, W. C., Farmer, S. W., and Hartwell, K. M. (1977). Effect of teleost pituitary growth hormone on growth of Tilapia mossambica and on growth and sea water adaptation of sockeye salmon $(O n-$ corhynchus nerka). Gen. Comp. Endocrinol. 33, 174-178.

Cook, A. F., Wilson, S. W., and Peter, R. E. (1983). Development and validation of a carp growth hormone radioimmunoassay. Gen. Comp. Endocrinol. 50, 335-347.

Daughaday, W. H. (1980). "Endocrine Control of Growth." Elsevier, New York.

Donaldson, E. M., Fagerlund, U. H. M., Higgs, D. A., and McBride, J. R. (1979). Hormonal enhancement of growth. In "Fish Physiology" (W. S. Hoar, D. J. Randall, and J. R. Brett, Eds.), Vol. VIII, pp. 456-597. Academic Press. New York.

Furuya, A., Ohtomo. T. I., Inada. T., and Yoshida. H. (1987). Generation and application of monoclonal antibodies against salmon somatotropin (salmon growth hormone) and salmon prolactin. Agric. Biol. Chem. 51, 2331-2335.

Greenwood, F. C., Hunter, W. M., and Glover, J. S (1963). The preparation of ${ }^{131}$ I labelled human GH of high specific radioactivity. Biochem. J. 89, 114-123.

Hirano, T., Prunet, P., Kawauchi, H., Takahashi, A., Ogasawara, T., Kubota, J., Nishioka, R. S., Bern, H. A., Takada, K., and Ishii, S. (1985). Development and validation of a salmon prolactin radioimmunoassay. Gen. Comp. Endocrinol. 59, 266-276.

Kishida, M., and Hirano, T. (1988). Development of radioimmunoassay for eel growth hormone. Nippon Suisan Gakkaishi 54, 1321-1327.

Komourdjian, M. P., Saunders, R. L., and Fenwick, J. C. (1976). The effect of porcine somatotropin on growth and survival in sea water of atlantic salmon (Salmo salar) parr. Can. J. Zool. 54, 531535.

Kordon, C. (1985). Neural mechanisms involved in pituitary control. Neurochem. Int. 7, 917-925.

Le Bail, P.-Y. (1988). Growth-reproduction interaction in Salmonids. In "Reproduction in Fish: Basic and Applied Aspects in Endocrinology and Genetics." pp. 91-108. Proceedings of the French Israeli Symposium, Tel Aviv, November 10-12, 1986, INRA Paris. 
Le Bail, P.-Y., Boulard, G., Barenton, B., and Zygmunt, M. (1989). Purification of chinook salmon (Oncorhynchus tshawytscha) GH for receptor study. Fish Physiol. Biochem. 7, 243-251.

Luo, D., and McKeown, B. A. (1989). Immunological evidence and physiological role of growth hormone releasing factor (GRF) in rainbow trout (Salmo gairdneri). "XIth Int. Symp. Comp. Endocrinol. Malaga, Spain, May 14-20, 1989," Abstr. p-211.

Marchant, T. A., and Peter, R. E. (1986). Seasonal variations in body growth rates and circulating levels of growth hormone in the goldfish, Carassius auratus. J. Exp. Biol. 237, 231-239.

Marchant, T., and Peter, R. E. (1989). Hypothalamic peptides influencing growth hormone secretion in the goldfish, Carassius auratus. Fish Physiol. Biochem. 7, 133-139.

Martal, J. (1972). Determination radioimmunologique des hormones de croissance ovine et bovine: Etude des conditions d'iodation et obtention d'une hormone somatotrope radioiodee sans prolactine contaminante. C.R. Acad. Sci. 274, 28932896.

McKeown, B. A., and Van Overbeeke, A. P. (1972). Prolactin and growth hormone concentrations in the serum and pituitary gland of adult migratory sockeye salmon (Oncorhynchus nerka). J. Fish. Res. Board Can. 29, 303-309.

Miwa, S., and Inui, Y. (1985). Effects of L-thyroxine and ovine growth hormone on smoltification of amago salmon (Oncorhynchus rhodorus). Gen. Comp. Endocrinol. 58, 436-442.

Muller, E. E. (1987). Neural control of somatotropic function. Physiol. Review's., 67, 962-1031.

Nicoll, C. (1975). Radioimmunoassay and radioreceptor assays for prolactin and growth hormone: A critical appraisal. Am. Zool. 15, 881-903.

Nishioka, R. S., Kelley, K. M., and Bern, H. A. (1988). Control of prolactin and growth hormone secretion in teleost fishes. Zool. Sci. 5, 267-280.

Nishioka, R. S., Richman, N. H., III, Young. G., Prunet, $P_{\text {. }}$, and Bern, H. A. (1987). Hypophysectomy of coho salmon (Oncorhynchus kisutch) and survival in fresh water and seawater. Aquaculture 65, 343-352.

Niu, P.-D. (1991). Etude du polymorphisme de la GH chez la truite arc-en-ciel (O. mykiss). These de l'Université de Rennes I. 125 pp.

Peter, R. E., Monckton, E. A., and McKeown, B. A. (1976). The effect of gold thioglucose on food intake, growth and forebrain histology in goldfish. Carassius auratus. Physiol. Behav. 17, 303-312.

Peter, R. E., Nahorniak, C. S., Vale, W. W., and Rivier, J. E. (1984). Human pancreatic growth hormone releasing factor (hpGRF) stimulates growth hormone release in the goldfish. J. Exp. Zool. 231, 161-163.

Pickering, A. D., Pottinger, T. G., Sumpter, J. P., Carragher, J. F., and Le Bail, P.-Y. (1991). Effects of acute and chronic stress on the levels of circulating growth hormone in the rainbow trout, Oncorhynchus mykiss. Gen. Comp. Endocrinol. 82.

Prunet, P., and Houdebine, L. M. (1984). Purification and biological characterization of chinook salmon prolactin. Gen. Comp. Endocrinol. 53, 49-57.

Prunet, P., Boeuf, G., Bolton, J., and Young, G (1989). Smoltification and sea water adaptation in atlantic salmon (Salmo salar): Plasma prolactin, growth hormone and thyroid hormones. Gen. Comp. Endocrinol. 74, 355-364.

Reiter, E. O., Morris, H. A., MacGillivray, M. H. and Weber, D. (1988). Variable estimate of serum growth hormone concentrations by different radioassay systems. J. Clin. Endocrinol. Metab. 66, 68-71.

Sekine, S.. Mizukami, T., Saito, A., Kawauchi, H., and Itoh. S. (1989). Isolation and Characterization of a novel growth hormone cDNA from chum salmon (Oncorhynchus keta). Biochim. Biophys. Acta 1009, 117-120.

Singh, H.. Griffith, R. W., Takahashi, A., Kawauchi, H., Thomas, P., and Stegman. J. J. (1988). Regulation of gonadal steroidogenesis in Fundulus heteroclitus by recombinant salmon growth hormone and purified salmon prolactin. Gen. Comp. Endocrinol. 72, 144-153.

Stacey, N. E., MacKenzie, D. S., Marchant, T. A., Kyle, A. L., and Peter, R. E. (1984). Endocrine changes during natural spawning in the white sucker, Catostomus commersoni. Gen. Comp. Endocrinol. 56, 333-348.

Sumpter, J. P., Le Bail, P.-Y., Pickering, A. D., Pottinger, T. G., and Carragher, J. F. (1991a). The effect of starvation on growth and plasma growth hormone concentrations of rainbow trout, Oncorhynchus mykiss. Gen. Comp. Endocrinol. 82.

Sumpter, J. P., Lincoln, R. F., Bye, V., Carragher, J. F., and Le Bail, P.-Y. (1991b). Plasma growth hormone levels during sexual maturation in diploid and triploid rainbow trout (Oncorhynchus mykiss), Gen. Comp. Endocrinol. 82.

Sweeting, R. M.. Wagner, G. F., and McKeown, B. A. (1985). Changes in plasma glucose, amino acid nitrogen and growth hormone during smoltification and seawater adaptation in coho salmon. Oncorhynchus kisutch. Aquaculture 45, 185-197.

Wagner, G. F., and McKeown, B. A. (1986). Development of a salmon growth hormone radioimmunoassay. Gen. Comp. Endocrinol. 62, 452-458.

Weil, C., Hansen, P., Hyam, D., Le Gac, F.. Breton, 
B., and Crim, L. W. (1986). Use of pituitary cells in primary culture to study the regulation of gonadotropin hormone (GTH) secretion in rainbow trout: Setting up and validating the system as assessed by its responsiveness to mammalian and salmon gonadotropin releasing hormone. Gen. Comp. Endocrinol. 62, 202-209.

Yao, K., Niu, P.-D., Le Gac, F., and Le Bail, P.-Y. (1990). Presence of $\mathrm{GH}$ specific binding sites in rainbow trout (Oncorhynchus mykiss) tissues: Characterization of the hepatic receptor. Gen. Comp. Endocrinol. 81, 72-82.

Young, G. (1988). Enhanced response of the interrenal of coho salmon (Oncorhynchus kisutch) to ACTH after growth hormone treatment in vivo and in vitro. Gen. Comp. Endocrinol. 71, 85-92.

Young, G., Björnsson, B. T., Prunet, P., Lin, R. J.. and Bern, H. A. (1989). Smoltification and sea water adaptation in coho salmon (Oncorhynchus kisutch): Plasma prolactin, growth hormone, thyroid hormone and cortisol. Gen. Comp. Endocrinol. 74, 335-345.

Zohar, Y. (1980). Dorsal aorta catheterization in rainbow trout (Salmo gairdneri). I. Its validity in the study of blood gonadotropin patterns. Reprod. Nutr. Dev. 20, 1811-1823. 